\title{
Evaluation of Solubility, Disintegration, and Dimensional Alterations of a Glass Ionomer Root Canal Sealer
}

\author{
Jacy Ribeiro CARVALHO-JÚNIOR ${ }^{1}$ \\ Luiz Fernando L. GUIMARÃES ${ }^{2}$ \\ Lourenço CORRER-SOBRINHO ${ }^{3}$ \\ Jesus D. PÉCORA ${ }^{4}$ \\ Manoel D. SOUSA-NETO ${ }^{1}$ \\ ${ }^{1}$ Faculty of Dentistry, University of Ribeirão Preto (UNAERP), Ribeirão Preto, SP, Brazil \\ ${ }^{2}$ Faculty of Pharmaceutical Sciences of Ribeirão Preto, University of São Paulo, Ribeirão Preto, SP, Brazil \\ ${ }^{3}$ Discipline of Dental Materials, Faculty of Dentistry of Piracicaba, UNICAMP, Piracicaba, SP, Brazil \\ ${ }^{4}$ Department of Restorative Dentistry, Faculty of Dentistry of Ribeirão Preto, University of São Paulo, \\ Ribeirão Preto, SP, Brazil
}

\begin{abstract}
The aim of this study was to evaluate the glass ionomer cement Ketac-Endo (K) compared with Endofill (E), N-Rickert (N), and Sealer $26(\mathrm{~S})$ in terms of disintegration, solubility, and dimensional alteration properties, based on ADA Specification No 57. For dimensional alterations, 12-mm high cylindric specimens measuring $6 \mathrm{~mm}$ in diameter were prepared and left to stand for a period corresponding to three times the setting time. These specimens were immersed in $30 \mathrm{ml}$ of deionized distilled water after measuring their length with a caliper. Thirty days later, the sample was removed from the container, dried and measured again for length to determine the percent of dimensional alteration. For solubility and disintegration, $1.5-\mathrm{mm}$ thick cement samples measuring $20 \mathrm{~mm}$ in diameter were prepared and left to stand for a period corresponding to three times the setting time. The samples were weighed and immersed in $50 \mathrm{ml}$ of deionized distilled water. After seven days, the samples were removed, dried and weighed again to determine the mass loss of each sample, expressed as percentage of original mass. This was considered to correspond to solubility and disintegration of cement. The results were: dimensional alteration: $\mathrm{E}(+0.14), \mathrm{K}(-0.24), \mathrm{N}(+0.23), \mathrm{S}(+3.26)$; for disintegration and solubility: E (3.90), K (9.90), $\mathrm{N}$ (3.00), S (0.25). We concluded that the dimensional alteration of all cements conformed to ADA standards; Endofill and Ketac-Endo sealers presented higher values for disintegration and solubility than ADA recommendations. Obturating a root canal with a sealer that presents low disintegration and low contraction could minimize the penetration of fluids into the root canal system, thus sealing the space hermetically.
\end{abstract}

Key Words: solubility, disintegration, dimensional alterations, endodontic sealers, physicochemical properties.

\section{INTRODUCTION}

The glass ionomer sealer was introduced in Dentistry by Wilson and Kent (1) in 1971, initially as a restorative material. According to McLean (2), this material presents advantages over the traditional restorative materials by having hydroxyapatite adhesiveness, anticariogenic properties because of constant fluoride liberation, and biological compatibility. In 1991, the glass ionomer cement was introduced as a root canal cement (Ketac-Endo, ESPE Dental-Medizin GmbH \& Co. KG, Seefeld, Germany). Since then, many studies have been carried out to determine the applicability of glass ionomer cement in modern Endodontics.

When studying the ideal properties of a filling material, it is possible to establish research parameters for the development of new products and to evaluate those already existing on the market. The properties of 
root canal cements can be divided into physicochemical, antimicrobial, and biological. The investigation of these properties was standardized after the publication of Specification 57 of the American Dental Association (ADA; American National Standards Institute) (3). This eliminated the problems caused by lack of standardization of tests performed (4), consequently permitting reproducible results and more reliable comparisons of the various materials and the data obtained in different studies.

Various studies related to physicochemical properties of glass-ionomer cements have been reported in the literature. Wu et al. $(5,6)$ reported that Ketac-Endo sealer provides lower apical microleakage when smaller film thickness is used. Kaplan et al. (7) reported that Ketac-Endo sealer presents higher disintegration when in contact with humidity before its complete setting time. Chung et al. (8), Najar (9), and Timpawat et al. (10) studied Ketac-Endo cement adhesiveness on dentin surface and verified that this cement presents low adhesiveness. Apical microleakage was the most studied property (11-13).

In this study, we have compared the Ketac-Endo glass ionomer cement with other types of root canal sealers in terms of their solubility, disintegration, and dimensional alterations.

\section{MATERIAL AND METHODS}

The materials studied were Ketac-Endo (ESPE, GBMH \& Co., Seefeld/Oberbay, Germany), Endofill (Dentsply-Herpo, Petrópolis, RJ, Brazil), N-Rickert (Inodon Laboratório, Porto Alegre, RS, Brazil), and Sealer 26 (Dentsply-Brasil, Petrópolis, RJ, Brazil). The dimensional alterations, solubility, and disintegration of the cements were determined according to ADA Specification 57 (American National Standards Institute, 1984) recommendations.

Table 1. Powder/fluid ratios and spatulation times of the cements studied.

\begin{tabular}{lcccc}
\hline Sealer & $\begin{array}{c}\text { Grams powder/0.20 ml } \\
\text { liquid (range) }\end{array}$ & Mean (g) & $\begin{array}{c}\text { Spatulation time } \\
\text { (range, s) }\end{array}$ & Mean (s) \\
\hline Endofill & $0.99-1.06$ & 1.03 & $111-123$ & 117 \\
Ketac-Endo & ND & ND & ND & ND \\
N-Rickert & $0.87-0.95$ & 0.92 & $96-110$ & 102 \\
Sealer 26 & $0.36-0.42$ & 0.39 & $80-89$ & 84 \\
\hline
\end{tabular}

$\mathrm{ND}=$ not done
The powder/liquid ratio and the spatulation time were determined by the method of Sousa-Neto et al. (14) (Table 1).

\section{Dimensional Alterations}

Teflon molds were prepared for the manufacture of 12-mm high cylindric samples measuring $6 \mathrm{~mm}$ in diameter. The mold was placed on a 1-mm thick, $25-\mathrm{mm}$ wide, and 75-mm long glass plate wrapped with a fine cellophane sheet. The mold was then filled until a slight excess of material was observed at its upper end. A microscope slide also wrapped in cellophane was then pressed onto the upper surface of the mold. The assembled microscope slide, cellophane-wrapped slide, and the mold containing the material in the middle were then kept firmly joined with the aid of a C-shaped clamp. Five minutes after the mixture was first prepared, the assembly was transferred to a chamber with $95 \%$ relative humidity and a temperature of $37^{\circ} \mathrm{C}$. The assembly was left to stand for a period corresponding to three times the setting time and removed from the chamber.

The next step consisted of filling the ends of the mold containing the sample with distilled and deionized water to obtain a regular surface. The sample was then removed from the mold, measured for length with a caliper, and stored in a 50- $\mathrm{ml}$ vessel containing $30 \mathrm{ml}$ of deionized distilled water at $37^{\circ} \mathrm{C}$ for 30 days. The sample was then removed from the container, blotted dry on absorbent paper, and measured again for length.

Percent dimensional alterations were calculated using the following formula: [(L30 days - L)/L], where L30 days is the length of the sample after 30 days of storage under the experimental conditions and $\mathrm{L}$ is the initial length of the sample. The arithmetic mean of five replicates was recorded as the dimensional alteration of the cement tested.

\section{Solubility and Disintegration}

A 1.5-mm-thick cylindric Teflon mold measuring $20 \mathrm{~mm}$ in inner diameter was filled with the material. The mold was supported by a glass plate of larger dimensions than the mold and covered with a cellophane sheet. The mold was filled to slight excess, an impermeable nylon thread was placed inside the material, and another 
glass plate, also covered with cellophane film, was positioned on the mold and pressed manually in such a way that the plates touched the entire mold in a uniform manner. The assembly was placed in a chamber with $95 \%$ relative humidity at $37^{\circ} \mathrm{C}$. The assembly was left to stand for a period corresponding to three times the setting time, and the samples were removed from the mold. Residues and loose particles were removed, the samples were weighed on an HM-200 precision scale (Bradford, MA, USA), and the weight was recorded.

The samples were suspended by the nylon thread and placed inside a plastic vessel with a wide mouth containing $50 \mathrm{ml}$ of distilled and deionized water, with care taken not to permit any contact between the sample and the inner surface of the container and the liquid. Each sample was placed in a container that was sealed and left in an oven at $37^{\circ} \mathrm{C}$ for 1 week. The samples were then removed from the containers, rinsed with distilled and deionized water, and blotted dry with absorbent paper. The samples were then placed in a dehumidifier for $24 \mathrm{~h}$ and weighed again.

This experiment was repeated five times. The weight loss of each sample, expressed as percentage of the original mass, was considered to correspond to the solubility and disintegration of the cement.

\section{Statistical Analysis}

When normality tests applied to the original data indicated that distribution was not normal, the KruskalWallis test was used. Significance was set at the level of $1 \%$. The rank means test was also used to analyze solubility and disintegration with significance set at the level of $0.01 \%$.

Table 2. Percent dimensional alteration of the cements studied.

\begin{tabular}{lcc}
\hline Sealer & $\begin{array}{c}\text { Dimensional alteration } \\
\text { (range) }\end{array}$ & $\begin{array}{c}\text { Mean } \\
(\%)\end{array}$ \\
\hline Endofill & +0.09 to +0.17 & +0.14 \\
Ketac-Endo & -0.09 to -0.43 & -0.24 \\
N-Rickert & +0.09 to +0.43 & +0.23 \\
Sealer 26 & +2.00 to +4.31 & +3.26 \\
\hline
\end{tabular}

$+=$ expansion; - = contraction.

\section{RESULTS}

\section{Dimensional Alterations}

The results of the tests of dimensional stability are presented in Table 2 . The Kruskal-Wallis test showed significance at the $1 \%$ level for a calculated $\mathrm{H}$ of 16.73 with a 0.08 probability of $\mathrm{H} 0$. Comparing the means pairwise, the cements used in this study differed significantly at $0.1 \%$ level, except the interaction Endofill versus $\mathrm{N}$-Rickert, that was not significantly different.

\section{Solubility and Disintegration}

The results of the solubility and disintegration tests are presented in Table 3 . The normality test applied to the original data (mass in $\mathrm{mg}$ ) indicated that distribution was not normal. On this basis, the KruskalWallis test was used, which indicated significance at the $1 \%$ level for an $\mathrm{H} 0$ probability of 0.07 for $\mathrm{H}$ equal to 16.91. The rank means of the cement samples were analyzed and showed that interaction between the cements used in this study differed significantly at the $0.1 \%$ level, except the interaction Endofill versus NRickert, that differed significantly at the $5 \%$ level.

It can be clearly seen that the cements used in this study present solubility and disintegration in the following increasing order: Sealer 26, N-Rickert, Endofill, and Ketac-Endo.

\section{DISCUSSION}

The dimensional alteration test recommended by ADA Specification 57 evaluates dimensional alter-

Table 3. Percent solubility and disintegration of the cements studied.

\begin{tabular}{lcc}
\hline Sealer & $\begin{array}{c}\text { \% Variation in weight } \\
\text { (range) }\end{array}$ & $\begin{array}{c}\text { Mean } \\
(\%)\end{array}$ \\
\hline Endofill & $3.67-4.17$ & 3.92 \\
Ketac-Endo & $7.70-10.76$ & 9.89 \\
N-Rickert & $2.40-4,10$ & 3.01 \\
Sealer 26 & $0.05-0.29$ & 0.23 \\
\hline
\end{tabular}


ations of filling materials after experimentation. ADA Specification 57 recommends that no cement should present contraction higher than $1 \%$. Therefore, all cements studied are according to the specification, being that only Ketac-Endo cement presented contraction $(0.24 \%)$.

Endofill and N-Rickert cements presented statistically equal dimensional alteration values, probably, because of the presence of gum rosin in their formulas, which according to Sousa-Neto et al. (14), is responsible for cement expansion.

Sealer 26 is an epoxy resin-based sealer that in this study presented an expansion of $3.26 \%$. This dimensional alteration could be explained by water sorption suffered by this type of resin after its polymerization (15). This requires further analysis of its chemical components.

Ketac-Endo cement presented little contraction $(0.24 \%)$, which may be related to ADA methodology that recommends that a sample be immersed in water after a period of three times the setting time of the material, which for Ketac-Endo would be 1 hour and 33 min. However, according Wilson and McLean (16), the setting time of this cement is completed only $24 \mathrm{~h}$ after mixture. Kaplan et al. (7) also reported that immersion of glass ionomer cement samples in water before 24 hours from the start of mixing increases disintegration because not enough time is given for complete setting. During the maturation time of glass ionomer cements, the presence of humidity may cause dissolution of anions and cations that form the matrix for areas surrounding the cement. This ion dissolution does not allow water, which is part of cement composition, to hydrate the matrix $\left(\mathrm{Ca}^{2+}\right.$ and $\mathrm{Al}^{3+}$ form polysalts with groups of $\mathrm{COO}^{-}$of polyacrylic acid), rendering it unstable. This process results in a weak, more soluble cement (16). Clinically, it is difficult to protect KetacEndo cement from water contamination during its application in root canals because of periapical tissues.

Although ADA Specification 57 considers the solubilization and disintegration test to be a single test, it is known that these processes are independent. Solubility is the ability of a substance to dissolve in another, expressed as the concentration of saturated solution of the former in the latter. Disintegration is the act or effect of separating from a whole. When solubility is tested, there is no particle in suspension (the solvent remains limpid), whereas in disintegration tests, there is a re- lease of sample particles that remain in suspension (the solvent becomes turbid). Endofill cement showed greater mass loss than N-Rickert cement, however in both cases, the solvent (water) was turbid, with powder on the bottom of the plastic vessel. The sample surface presented areas with a peeling aspect. In this test, it was observed that Sealer 26 cement presented little mass loss, without particles in suspension, describing solubility. Despite the high value of Ketac-Endo cement in the solubility and disintegration test, the solvent presented limpid, describing also solubility.

ADA Specification 57 tolerates $3 \%$ as the maximum value accepted for solubility and disintegration. Table 3 shows that Endofill and Ketac-Endo cements presented solubility and disintegration values greater than accepted by the ADA standard: $3.92 \%$ and $9.89 \%$, respectively. N-Rickert cement presented an average value of $3.01 \%$, being at the limit of ADA Specification 57. Sealer 26 cement showed the lowest solubility value $(0.25 \%)$.

Wilson and Batchelor (17) explained the disintegration mechanism of zinc oxide and eugenol cements as one consequence of continuous eugenol loss of cement matrix by lixiviation, decomposing the balance between this matrix and eugenol.

Savioli (18) reported that anhydrous sodium tetraborate in Grossman cement promotes increasing solubility because it is very soluble. Similarly, the presence of sodium borate in Endofill promoted its increasing solubility. This author also reported a reduction in solubility and disintegration for zinc oxide and eugenol-based cements when natural resin was added to their composition.

The presence of the soluble salt aristol in $\mathrm{N}$ Rickert cement negatively influences the solubility and disintegration test result (19).

Solubility and disintegration of root canal sealers must be as small as possible so that it can promote hermetic sealing, thus favoring clinical success, because microleakage may occur from the cervical to apical third or inversely.

We conclude that all cements studied are according to ADA Specification 57 for the dimensional alteration property, being that only Ketac-Endo cement presented little contraction. In terms of solubility and disintegration, Ketac-Endo and Endofill cements presented higher values than accepted by the Specification. Sealer 26 and N-Rickert cements were according to 
ADA recommendations, with Sealer 26 presenting the lowest solubility and disintegration values.

\section{RESUMO}

O objetivo deste trabalho foi avaliar o comportamento do cimento à base de ionômero de vidro Ketac-Endo $(\mathrm{K})$ comparado com os cimentos Endofill (E), N-Rickert (N) e Sealer 26 (S), em relação às propriedades de estabilidade dimensional e solubilidade $\mathrm{e}$ desintegração, com base na Especificação n ${ }^{\circ} 57$ da ADA. Para estabilidade dimensional, confeccionaram-se corpos de prova cilíndricos dos cimentos, com dimensões de $12 \mathrm{~mm}$ de altura por $6 \mathrm{~mm}$ de diâmetro, passado 3 vezes o tempo de endurecimento do cimento. Após mensuração de seus comprimentos com um paquímetro digital, esses foram imersos em $30 \mathrm{ml}$ de água destilada. Decorrido trinta dias, o corpo de prova foi removido, seco e medido novamente. Com os valores do comprimento inicial e final, determinou-se a variação percentual que ocorre nos corpos de prova. Para solubilidade e desintegração, confeccionaram-se corpos de prova dos cimentos, com 1,5 mm de espessura e $20 \mathrm{~mm}$ de diâmetro, passado 3 vezes o tempo de endurecimento do cimento. Os corpos de prova tiveram sua massa pesada e foram imersos em $50 \mathrm{ml}$ de água destilada. Decorrido sete dias, o corpo de prova foi removido, seco e pesado novamente. A solubilidade e desintegração foram consideradas como a perda de massa de cada amostra, expressas como porcentagem da massa original. Os resultados foram: para estabilidade dimensional: E $(+0,14), \mathrm{K}(-0,24) \mathrm{N}(+0,23), \mathrm{S}$ $(+3,26)$; para solubilidade e desintegração: $\mathrm{E}(3,90), \mathrm{K}(9,90), \mathrm{N}$ $(3,00), S(0,25)$. Concluiu-se que, em relação a estabilidade dimensional todos os cimentos encontram-se dentro das normas da ADA; quanto a solubilidade e desintegração os cimentos Endofill e Ketac-Endo apresentaram valores acima do determinado pela ADA. Obturando um canal radicular com um cimento que apresenta baixa disintegração e contração pode minimizar a penetração dos fluidos para o interior do sistema radicular, selando o espaço hermeticamente.

\section{ACKNOWLEDGMENTS}

Research supported by a grant from FAPESP (process no. 00/03290-0).

\section{REFERENCES}

1. Wilson AD, Kent BE. New translucent cement for dentistry. The glass ionomer cement. Br Dent J 1972;132:133-135.

2. McLean JW. The clinical use of glass-ionomer cements. Dent
Clin N Am 1992;36:693-711.

3. ANSI/ADA Specification no. 57 for endodontic filling materials. J Am Dent Assoc 1984;108:88.

4. Branstetter J, Fraunhofer JA. The physical properties and sealing action of endodontic sealer cements: a review of the literature. J Endodon 1982;8:312-316.

5. Wu M-K, De Gee AJ, Wesselink PR. Leakage of 4 root canal sealers at different thickness. Int Endod J 1994;27:304-308.

6. Wu M-K, Wesselink PR, Boersma J. A 1-year follow-up study on leakage of four root canal sealers at different thicknesses. Int Endod J 1995;28:185-189.

7. Kaplan AE, Goldberg F, Artaza LP, De Silvio A, Macchi RL. Disintegration of endodontic cements in water. J Endodon 1997;23:439-441.

8. Chung HA, Titley K, Torneck CD, Lawrence HP, Friedman S. Adhesion of glass-ionomer cement sealers to bovine dentin conditioned with intracanal medications. J Endodon 2001;27:85-88.

9. Najar AL, Vansan LP, Saquy PC, Sousa Neto MD. Adhesion of a glass-ionomer root canal sealer to the human dentin. Aust Endodon J (in press)

10. Timpawat S, Harnirattisai C, Senawongs P. Adhesion of a glassionomer root canal sealer to the root canal wall. J Endodon 2001;27:168-171.

11. De Gee AJ, Wu MK, Wesseling PR. Sealing properties of KetacEndo glass ionomer cement and AH-26 root canal sealers. Int Endod J 1994;27:239-244.

12. Goldberg F, Artaza LP, De Silvio A. Apical sealing ability of a new glass ionomer root canal sealer. J Endodon 1995;21:498 500 .

13. De Almeida WA, Leonardo MR, Tanomaru Filho M, Silva LAB Evaluation of apical sealing of three endodontic sealers. Int Endod J 2000;33:25-27.

14. Sousa-Neto MD, Guimarães LF, Saquy PC, Pécora JD. Effect of different grades of gum rosins and hydrogenated resins on the solubility, disintegration, and dimensional alterations of Grossman cement. J Endodon 1999;25:477-480.

15. Phillips RW. Skinner's Science of Dental Materials. 9th ed. Philadelphia: WB Saunders, 1991.

16. Wilson AD, McLean JW. Glass Ionomer Cements. Chicago: Quintessence; 1988.

17. Wilson AD, Batchelor RF. Zinc oxide-eugenol cements: II. Study of erosion and disintegration. J Dent Res 1970;49:593-598.

18. Savioli RN. Estudo da influência de cada componente químico do cimento de Grossman sobre as suas propriedades físicas. [Master's thesis]. Ribeirão Preto: Faculdade de Odontologia de Ribeirão Preto, Universidade de São Paulo; 1992. 123 p. Available at http://www.forp.usp.br/restauradora/Teses/Savioli/ Savimaster/Savimaster.html

19. Savioli RN. Avaliação das propriedades físico-químicas de alguns cimentos endodônticos. [Doctoral thesis]. Ribeirão Preto: Faculdade de Odontologia de Ribeirão Preto, Universidade de São Paulo; 1998. 62 p. Available at http://www.forp.usp.br/ restauradora/Teses/Savioli/Doutor2.html

Accepted December 15, 2002 